\title{
The Role of High Density Lipoproteins in Thrombosis
}

\author{
Marina Cuchel and Daniel J. Rader* \\ University of Pennsylvania School of Medicine, Department of Medicine, Philadelphia
}

Received October 10, 2001; Revised November 21, 2001; Accepted November 27, 2001; Published January 12, 2002

Lipids and lipoproteins, as well as factors involved in hemostasis and thrombosis, play a central role in the pathogenesis of cardio- and cerebrovascular disease. In recent years it has become clear that a strong association exists between coagulation factors and plasma lipoproteins. Anionic phospholipids are necessary for the optimal activity of both pro- and anticoagulant enzymatic complexes. Cell membranes have traditionally been considered to provide the essential lipid-containing surfaces. However, in light of recent studies, plasma lipoproteins are also believed to provide appropriate surfaces to support coagulation. While triglyceride-rich lipoproteins and oxidized low-density lipoproteins are associated with a procoagulant profile, high-density lipoproteins (HDL) may have an anticoagulant effect. This paper reviews scientific data on the potential role of $\mathrm{HDL}$ as modulator of thrombotic processes.

KEY WORDS: high density lipoprotein, coagulation, thrombosis, platelets, platelet aggregation, activated protein $\mathrm{C}$

DOMAINS: thrombosis, atherosclerosis, cardiovascular biology, hematology

\section{INTRODUCTION}

Atherosclerotic cardiovascular disease is the most common cause of morbidity and mortality in the Western world[1]. Atherosclerotic and thrombotic processes are closely linked in the pathogenesis of atherosclerotic cardiovascular disease, and thrombosis is usually the final event that leads to the acute occlusion of an atherosclerotic vessel[2]. Plasma lipids and lipoproteins are able to modulate hemostasis and thrombosis by interacting with thrombotic, fibrinolytic, and rheologic factors (for review see [3,4]). Lipid-rich surfaces, in particular those containing anionic phospholipids, are essential for the activity of both pro- and anticoagulant enzyme complexes[5]. Atherogenic lipoproteins, triglyceride-rich lipoproteins in particular, are associated with a procoagulant profile[6,7,8,9]. In addition, triglyceride-rich lipoproteins and oxidized low-density lipoproteins (LDL) can support the activity of procoagulant complexes[10,11]. In contrast, highdensity lipoproteins (HDL) seem to have anticoagulant effects[4].

The protective role of HDL against cardiovascular disease is well established[12]. Low levels of HDL cholesterol are frequently found in patients with premature coronary heart disease[13,14] and stroke[15,16]. High HDL cholesterol syndromes are often associated with 
longevity and decreased incidence of cardiovascular disease[17]. Furthermore, pharmacological intervention to increase HDL cholesterol resulted in a decreased incidence in coronary events[18,19] and stroke[20].

HDL are a heterogeneous class of particles comprised of lipids and proteins with density of $1.063-1.21 \mathrm{~g} / \mathrm{ml}$. As with other lipoproteins, their core contains mostly cholesteryl ester and triglyceride, and their surface contains phospholipid, free cholesterol, and apolipoprotein (apo)[21]. The two major HDL subfractions are $\mathrm{HDL}_{2}(\mathrm{~d}=1.063-1.125 \mathrm{~g} / \mathrm{ml})$ and $\mathrm{HDL}_{3}(\mathrm{~d}=$ $1.125-1.21 \mathrm{~g} / \mathrm{ml})$. These differ in size and protein composition, with $\mathrm{HDL}_{2}$ being larger and lipid rich, and $\mathrm{HDL}_{3}$ smaller and with a higher content of proteins. The major HDL apolipoprotein is apo A-I, which is synthesized and secreted by the intestine and the liver, but other apolipoproteins as apo AII, E, C, as well as enzymes and transfer proteins are found on HDL surface and are actively exchanged with other lipoproteins.

One mechanism by which HDL and apo A-I are antiatherogenic is through their ability to promote cholesterol efflux from peripheral cells and return this cholesterol to the liver for excretion into bile, a process known as reverse cholesterol transport[22,23]. However, there are likely to be additional cellular and molecular mechanisms by which HDL and apo A-I protect from cardiovascular disease. For example it has been demonstrated that apo A-I and HDL can prevent LDL oxidation[24], protect endothelial cells against the effect of oxidized LDL[25], and prevent the cytokine-induced upregulation of adhesion molecules on endothelial cells[26,27]. As previously mentioned, data in the literature also suggest that HDL particles may have an anticoagulant effect. This review will focus on the potential role of HDL as modulators of thrombotic processes, particularly through their effects on platelet aggregation and on the protein C pathway.

\section{HDL AS AN INHIBITOR OF PLATELET AGGREGATION AND PLATELET- DEPENDENT THROMBUS FORMATION}

Platelets play a central role in thrombotic events. Very low-density lipoproteins (VLDL) and LDL are known to promote platelet aggregation and are positively associated with the development of platelet-dependent thrombosis[28,29,30,31]. In contrast, HDL may have the opposite effect. Although early data were conflicting[32,33], more recent data showed that HDL particles have an inhibitory effect on platelet aggregation. HDL[34,35] and apo A-I Milano, a variant of apo AI[36], have been shown to inhibit platelet aggregation as well as platelet-dependent thrombus formation in vitro and ex vivo. HDL particles enriched in apo E seem to be particularly able to inhibit ADP-, collagen-, and epinephrine-induced platelet aggregation[37]. Interestingly, platelets of subjects with low HDL-cholesterol levels have been shown to be hyperactive[38]. Moreover, platelets of a patient with Tangier disease, a syndrome characterized by HDL deficiency, were hyper-responsive to low doses of an aggregating agent[39], although hyporesponsiveness was reported in another study[40].

The mechanism underlying the effects of HDL on platelet function is not known. HDL could affect platelet aggregation indirectly. Apo A-I is known to stabilize prostacyclin[41,42] and could consequently enhance its antiaggregative effect. But a more direct effect is suggested by several studies showing that platelets can bind HDL subfractions in a process that is specific, rapid, insensitive to temperature, and independent of divalent ions[37,43,44]. The binding site for HDL particles on the platelet surface is still debated. Data from a study by Koller et al.[45] suggested that $\mathrm{HDL}_{3}$ particles, as well as LDL, are able to bind to the glycoprotein IIb/IIIa complex both on isolated platelet membranes and intact platelets and to inhibit the binding of fibrinogen to the same receptor[45]. However these results were not confirmed by Pedreño et al.[46] who were unable to demonstrate HDL-binding to either the glycoprotein IIb/IIIa complex or the individual subunits. 
It is possible that the HDL-related effects on platelet function are mediated by the release of second messengers following the binding of the lipoprotein particle to the platelet receptor. It has been reported that $\mathrm{HDL}_{3}$ binding to human platelets is associated with the hydrolysis of phosphatidylcholine and the release of 1,2-diacylglycerol (DAG), possibly due to the activation of phospholipase C[47]. This signaling pathway is desensitized and downregulated by a protein kinase $\mathrm{C}$-mediated mechanism[44,48]. Furthermore preincubation with $\mathrm{HDL}_{3}$ at physiologically relevant concentrations inhibits thrombin-induced platelet fibrinogen binding and aggregation[49]. This inhibitory effect is associated with slower turnover of phosphatidyl inositol bisphosphate, reduced formation of the second messengers DAG and inositol trisphosphate, and reduced intracellular $\mathrm{Ca}^{2+}$ mobilization, all events that are known to lead to fibrinogen binding and platelet aggregation[49]. These are probably transient events, because platelets undergo desensitization with longer incubation time[49]. Nevertheless, these studies support the hypothesis that HDL could impair platelet responsiveness to exogenous stimuli via a direct mechanism.

\section{HDL AS A COFACTOR FOR THE PROTEIN C PATHWAY}

The protein $\mathrm{C}$ pathway is very important in maintaining a balance between coagulation and fibrinolysis[4]. A poor response to activated protein C (APC) is associated with venous[50,51] and arterial thrombosis at both cardio- and cerebrovascular sites[52,53,54]. Furthermore, it has been reported that the risk of ischemic stroke is inversely correlated with protein C levels[55], and protein $\mathrm{C}$ has been found neuroprotective for cerebral arterial thrombosis in a mouse model[56].

Griffin et al.[57] have shown in in vitro experiments that HDL markedly enhanced inactivation of factor Va in the presence of APC and protein S at physiologic levels. While both HDL and LDL phospholipid extracts are able to enhance the inactivation of factor Va, only HDL particles as a whole, and not LDL, showed anticoagulant properties as a cofactor in the protein C pathway. Furthermore, while phospholipid vesicles can have both anti- and procoagulant effects, depending on their concentration, HDL particles showed only anticoagulant properties. This group also demonstrated that the anticoagulant activity was linked to the presence of apo A-I and that apo A-I concentration significantly correlated with the results of a modified partial prothrombin assay[57]. They suggested that the anticoagulant properties of HDL may be due to the presence of phosphatidylethanolamine (PE) on the lipoprotein. PE has been showed to enhance activity of the protein $\mathrm{C}$ pathway[58]. People with high plasma HDL cholesterol levels have relatively higher content in PE in the HDL fraction as compared with subjects with low plasma HDL cholesterol levels[59].

APC resistance was first identified in subjects with a mutation in factor V, called Factor V Leiden[60]. Although these patients are at high risk of thrombosis, many patients with thrombosis and APC resistance have a normal factor V genotype[52,53,54]. Other factors are believed to contribute to the modulation of APC activity and of that of its cofactor, protein S. The hypothesis that HDL is involved in a protective mechanism against atherothrombosis through the modulation of the protein $\mathrm{C}$ pathway is intriguing and deserves further study.

\section{HDL AS MODULATOR OF OTHER STEPS OF THROMBOSIS}

Data suggest that HDL may modulate thrombotic processes via other potential mechanisms. HDL-apo AII has been shown to inhibit the activation of factor X by the tissue factor-factor VIIa complex, inhibiting the first step of the extrinsic coagulation pathway[61]. In addition, the tissue factor pathway inhibitor (TFPI) is known to exist in plasma in a free form and in a form bound to lipoproteins, including HDL[62,63,64]. More studies are needed to better understand the physiological implication of these observations. 


\section{SUMMARY}

Thrombus formation is the final event that leads to acute ischemic episodes. The severity of the ischemic episode depends, in part, on factors that are able to modulate the formation and the stability of the thrombus. HDL may be able to modulate the thrombotic process through at least two different mechanisms: inhibition of platelet aggregation and enhancement of the protein $\mathrm{C}$ pathway. These antithrombotic properties may be one of the different mechanisms explaining the protective role of HDL against atherothrombotic cardiovascular disease.

\section{ACKNOWLEDGMENT}

Dr. Cuchel is supported by NIH Training Grant DK07748. Dr. Rader is an Established Investigator of the American Heart Association and a recipient of the Burroughs Wellcome Foundation Clinical Scientist Award in Translational Research.

\section{REFERENCES}

1. Breslow, J.L. (1997) Cardiovascular disease burden increases, NIH funding decreases. Nat. Med. 3, 600-601.

2. Fuster, V., Fallon, J.T., Badimon, J.J., and Nemerson, Y. (1997) The unstable atherosclerotic plaque: clinical significance and therapeutic intervention. Thromb. Haemost. 78, 247-255.

3. Rosenson, R.S. and Lowe, G.D. (1998) Effects of lipids and lipoproteins on thrombosis and rheology. Atherosclerosis 140(2), 271-280.

4. Griffin, J.H., Fernandez, J.A., and Deguchi, H. (2001) Plasma lipoproteins, hemostasis and thrombosis. Thromb. Haemost. 86(1), 386-394.

5. Zwaal, R.F., Comfurius, P., and Bevers, E.M. (1998) Lipid-protein interactions in blood coagulation. Biochim. Biophys. Acta 1376(3), 433-453.

6. Silveira, A., Karpe, F., Blomback, M., Steiner, G., Walldius, G., and Hamsten, A. (1994) Activation of coagulation factor VII during alimentary lipemia. Arterioscler. Thromb. 14(1), 60-69.

7. Mitropoulos, K.A., Miller, G.J., Watts, G.F., and Durrington, P.N. (1992) Lipolysis of triglyceride-rich lipoproteins activates coagulant factor XII: a study in familial lipoprotein-lipase deficiency. Atherosclerosis 95(2-3), 119-125.

8. Mussoni, L., Mannucci, L., Sirtori, M., Camera, M., Maderna, P., Sironi, L., and Tremoli, E. (1992) Hypertriglyceridemia and regulation of fibrinolytic activity. Arterioscler. Thromb. 12(1), 19-27.

9. MacCallum, P.K., Cooper, J.A., Martin, J., Howarth, D.J, Meade, T.W., and Miller, G.J. (2000) Haemostatic and lipid determinants of prothrombin fragment F1.2 and D- dimer in plasma. Thromb. Haemost. 83(3), 421426.

10. Moyer, M.P., Tracy, R.P., Tracy, P.B., van't Veer, C., Sparks, C.E., and Mann, K.G. (1998) Plasma lipoproteins support prothrombinase and other procoagulant enzymatic complexes. Arterioscler. Thromb. Vasc. Biol. 18(3), 458-465.

11. Rota, S., McWilliam, N.A., Baglin, T.P., and Byrne, C.D. (1998) Atherogenic lipoproteins support assembly of the prothrombinase complex and thrombin generation: modulation by oxidation and vitamin E. Blood 91(2), 508-515.

12. Gordon, D.J. and Rifkind, B.M. (1989) High-density lipoproteins--the clinical implications of recent studies. N. Engl. J. Med. 321, 1311-1316.

13. Genest, J., Bard, J.M., Fruchart, J.C., Ordovas, J.M., and Schaefer, E.J. (1993) Familial hypoalphalipoproteinemia in premature coronary artery disease. Arterioscler. Thromb. 13, 1728-1737.

14. Bolibar, I., von Eckardstein, A., Assmann, G., and Thompson, S. (2000) Short-term prognostic value of lipid measurements in patients with angina pectoris. The ECAT Angina Pectoris Study Group: European Concerted Action on Thrombosis and Disabilities. Thromb. Haemost. 84(6), 955-960.

15. Sacco, R.L., Benson, R.T., Kargman, D.E., Boden-Albala, B., Tuck, C., Lin, I.F., Cheng, J.F., Paik, M.C., Shea, S., and Berglund, L. (2001) High-density lipoprotein cholesterol and ischemic stroke in the elderly: the Northern Manhattan Stroke Study. JAMA 285(21), 2729-2735.

16. Tanne, D., Yaari, S., and Goldbourt, U. (1997) High-density lipoprotein cholesterol and risk of ischemic stroke mortality. A 21-year follow-up of 8586 men from the Israeli Ischemic Heart Disease Study. Stroke 28(1), 83-87.

17. Glueck, C.J., Fallat, R.W., Millett, F., Gartside, P., Elston, R.C., and Go, R.C. (1975) Familial hyper-alphalipoproteinenia: studies in eighteen kindreds. Metabolism 24(11), 1243-1265. 
18. Manninen, V., Elo, M.O., Frick, M.F., Haapa, K., Heinonen, O.P., Heinsalmi, P., Helo, P., Huttunen, J.K., Kaitaniemi, P., Koskinen, P., Maenpaa, H., Malkonen, J., Manttari, M., Norola, S., Pasternack, A., Pikkarainen, J., Romo, M., Sjoblom, T., and Nikkila, E.A. (1988) Lipid alterations and decline in the incidence of coronary heart disease in the Helsinki heart study. JAMA 260, 641-651.

19. Rubins, H.B., Robins, S.J., Collins, D., Fye, C.L., Anderson, J.W., Elam, M.B., Faas, F.H., Linares, E., Schaefer, E.J., Schectman, G., Wilt, T.J., and Wittes, J. (1999) Gemfibrozil for the secondary prevention of coronary herat disease in men with low levels of high-density lipoprotein cholesterol. N. Engl. J. Med. 341, 410-418.

20. Bloomfield, R.H., Davenport, J., Babikian, V., Brass, L.M., Collins, D., Wexler, L., Wagner, S., Papademetriou, V., Rutan, G., and Robins, S.J. (2001) Reduction in stroke with gemfibrozil in men with coronary heart disease and low HDL cholesterol: the Veterans Affairs HDL Intervention Trial (VA-HIT). Circulation 103(23), 2828-2833.

21. Rader, D.J. and Ikewaki, K. (1996) Unravelling high density lipoprotein-apolipoprotein metabolism in human mutants and animal models. Curr. Opin. Lipidol. 7, 117-123.

22. Fielding, C.J. and Fielding, P.E. (1995) Molecular physiology of reverse cholesterol transport. J. Lipid Res. 36(2), 211-228.

23. Stein, O. and Stein, Y. (1999) Atheroprotective mechanisms of HDL. Atherosclerosis 144(2), $285-301$.

24. Parthasarathy, S., Barnett, J., and Fong, L.G. (1990) High density lipoprotein inhibits the oxidative modification of low density lipoprotein. Biochim. Biophys. Acta 1044, 275-283.

25. Suc, I., Escargueil-Blanc, I., Troly, M., Salvayre, R., and Negre-Salvayre, A. (1997) HDL and ApoA prevent cell death of endothelial cells induced by oxidized LDL. Arterioscler. Thromb. Vasc. Biol. 17, 2159-2166.

26. Cockerill, G., Rye, K., Gamble, J., Vadas, M.A., and Barter, P.J. (1995) High density lipoproteins inhibit cytokine-induced expression of endothelial cell adhesion molecules. Arterioscler. Thromb. Vasc. Biol. 15, 1987-1994.

27. Cockerill, G.W., Saklatvala, J., Ridley, S.H., Yarwood, H., Miller, N.E., Oral, B., Nithyanathan, S., Taylor, G., and Haskard, D.O. (1999) High-density lipoproteins differentially modulate cytokine-induced expression of E-selectin and cyclooxygenase-2. Arterioscler. Thromb. Vasc. Biol. 19(4), 910-917.

28. Lacoste, L., Lam, J.Y., Hung, J., Letchacovski, G., Solymoss, C.B., and Waters, D. (1995) Hyperlipidemia and coronary disease. Correction of the increased thrombogenic potential with cholesterol reduction. Circulation 92, 3172-3177.

29. Brook, J.G. and Aviram, M. (1988) Platelet lipoprotein interactions. Semin. Thromb. Hemost. 14(3), 258265.

30. Badimon, J.J., Badimon, L., Turitto, V.T., and Fuster, V. (1991) Platelet deposition at high shear rates is enhanced by high plasma cholesterol levels. In vivo study in the rabbit model. Arterioscler. Thromb. 11(2), 395-402.

31. Cadroy, Y., Lemozy, S., Diquelou, A., Ferrieres, J., Douste-Blazy, P., Boneu, B., and Sakariassen, K.S. (1993) Human type II hyperlipoproteinemia enhances platelet-collagen adhesion in flowing nonanticoagulated blood. Arterioscler. Thromb. 13(11), 1650-1653.

32. Aviram, M. and Brook, J.G. (1983) Characterization of the effect of plasma lipoproteins on platelet function in vitro. Haemostasis 13(6), 344-350.

33. Hassall, D.G., Owen, J.S., and Bruckdorfer, K.R. (1983) The aggregation of isolated human platelets in the presence of lipoproteins and prostacyclin. Biochem. J. 216(1), 43-49.

34. Pajkrt, D., Lerch, P.G., van der Poll, T., Levi, M., Illi, M., Doran, J.E., Arnet, B., van den Ende, A., ten Cate, J.W., and van Deventer, S.J. (1997) Differential effects of reconstituted high-density lipoprotein on coagulation, fibrinolysis and platelet activation during human endotoxemia. Thromb. Haemost. 77(2), 303307.

35. Naqvi, T.Z., Shah, P.K., Ivey, P.A., Molloy, M.D., Thomas, A.M., Panicker, S., Ahmed, A., Cercek, B., and Kaul, S. (1999) Evidence that high-density lipoprotein cholesterol is an independent predictor of acute platelet-dependent thrombus formation. Am. J. Cardiol. 84(9), 1011-1017.

36. Li, D., Weng, S., Yang, B., Zander, D.S., Saldeen, T., Nichols, W.W., Khan, S., and Mehta, J.L. (1999) Inhibition of arterial thrombus formation by ApoA1 Milano. Arterioscler. Thromb. Vasc. Biol. 19(2), 378-383.

37. Desai, K., Bruckdorfer, K.R., Hutton, R.A., and Owen, J.S. (1989) Binding of apoE-rich high density lipoprotein particles by saturable sites on human blood platelets inhibits agonist-induced platelet aggregation. J. Lipid Res. 30(6), 831-840.

38. Bierenbaum, M.L., Fleischman, A.I., Stier, A., Watson, P., Somol, H., Naso, A.M., and Binder, M. (1979) Increased platelet aggregation and decreased high-density lipoprotein cholesterol in women on oral contraceptives. Am. J. Obstet. Gynecol. 134(6), 638-641.

39. Vergani, C.G., Plancher, A.C., Zuin, M., Cattaneo, M., Tramaloni, C., Maccari, S., Roma, P., and Catapano, A.L. (1984) Bile lipid composition and haemostatic variables in a case of high density lipoprotein deficiency (Tangier disease). Eur. J. Clin. Invest. 14(1), 49-54.

40. Shastri, K.M., Carvalho, A.C., and Lees, R.S. (1980) Platelet function and platelet lipid composition in the dyslipoproteinemias. J. Lipid Res. 21(4), 467-472. 
41. Yui, Y., Aoyama, T., Morishita, H., Takahashi, M., Takatsu, Y., and Kawai, C. (1988) Serum prostacyclin stabilizing factor is identical to apolipoprotein A- I (Apo A-I). A novel function of Apo A-I. J. Clin. Invest. 82(3), 803-807.

42. Aoyama, T., Yui, Y., Morishita, H., and Kawai, C. (1990) Prostaglandin I2 half-life regulated by high density lipoprotein is decreased in acute myocardial infarction and unstable angina pectoris. Circulation 81(6), 1784-1791.

43. Koller, E., Koller, F., and Doleschel, W. (1982) Specific binding sites on human blood platelets for plasma lipoproteins. Hoppe Seylers Z. Physiol. Chem. 363(4), 395-405.

44. Pedreno, J., Vila, M., and Masana, L. (1999) Mechanisms for regulating platelet high density lipoprotein type3 binding sites: evidence that binding sites are downregulated by a protein kinase C-dependent mechanism. Thromb. Res. 94(1), 33-44.

45. Koller, E., Koller, F., and Binder, B.R. (1989) Purification and identification of the lipoprotein-binding proteins from human blood platelet membrane. J. Biol. Chem. 264(21), 12412-12418.

46. Pedreno, J., de Castellarnau, C., and Masana, L. (2001) Platelet HDL(3) binding sites are not related to integrin alpha(IIb)beta(3) (GPIIb-IIIa). Atherosclerosis 154(1), 23-29.

47. Nazih, H., Devred, D., Martin-Nizard, F., Clavey, V., Fruchart, J.C., and Delbart, C. (1992) Pertussis toxin sensitive G-protein coupling of HDL receptor to phospholipase C in human platelets. Thromb. Res. 67(5), 559-567.

48. Nazih, H., Nazih-Sanderson, F., Magret, V., Caron, B., Goudemand, J., Fruchart, J.C., and Delbart, C. (1994) Protein kinase C-dependent desensitization of HDL3-activated phospholipase C in human platelets. Arterioscler. Thromb. 14(8), 1321-1326.

49. Nofer, J.R., Walter, M., Kehrel, B., Wierwille, S., Tepel, M., Seedorf, U., and Assmann, G. (1998) HDL3mediated inhibition of thrombin-induced platelet aggregation and fibrinogen binding occurs via decreased production of phosphoinositide-derived second messengers 1,2-diacylglycerol and inositol 1,4,5-trisphosphate. Arterioscler. Thromb. Vasc. Biol. 18(6), 861-869.

50. Koster, T., Rosendaal, F.R., de Ronde, H., Briet, E., Vandenbroucke, J.P., and Bertina, R.M. (1993) Venous thrombosis due to poor anticoagulant response to activated protein C: Leiden Thrombophilia Study. Lancet 342(8886-8887), 1503-1506.

51. Svensson, P.J. and Dahlback, B. (1994) Resistance to activated protein C as a basis for venous thrombosis. $N$. Engl. J. Med. 330(8), 517-522.

52. Kiechl, S., Muigg, A., Santer, P., Mitterer, M., Egger, G., Oberhollenzer, M., Oberhollenzer, F., Mayr, A., Gasperi, A., Poewe, W., and Willeit, J. (1999) Poor response to activated protein C as a prominent risk predictor of advanced atherosclerosis and arterial disease. Circulation 99(5), 614-619.

53. van der Bom, J.G., Bots, M.L., Haverkate, F., Slagboom, P.E., Meijer, P., de Jong, P.T., Hofman, A., Grobbee, D.E., and Kluft, C. (1996) Reduced response to activated protein C is associated with increased risk for cerebrovascular disease. Ann. Intern. Med. 125(4), 265-269.

54. Fisher, M., Fernandez, J.A., Ameriso, S.F., Xie, D., Gruber, A., Paganini-Hill, A., and Griffin, J.H. (1996) Activated protein $\mathrm{C}$ resistance in ischemic stroke not due to factor $\mathrm{V}$ arginine506--> glutamine mutation. Stroke 27(7), 1163-1166.

55. Folsom, A.R., Rosamond, W.D., Shahar, E., Cooper, L.S., Aleksic, N., Nieto, F.J., Rasmussen, M.L., and Wu, K.K. (1999) Prospective study of markers of hemostatic function with risk of ischemic stroke. The Atherosclerosis Risk in Communities (ARIC) Study Investigators. Circulation 100(7), 736-742.

56. Shibata, M., Kumar, S.R., Amar, A., Fernandez, J.A., Hofman, F., Griffin, J.H., and Zlokovic, B.V. (2001) Anti-inflammatory, antithrombotic, and neuroprotective effects of activated protein $\mathrm{C}$ in a murine model of focal ischemic stroke. Circulation 103(13), 1799-1805.

57. Griffin, J.H., Kojima, K., Banka, C.L., Curtiss, L.K., and Fernandez, J.A. (1999) High-density lipoprotein enhancement of anticoagulant activities of plasma protein $\mathrm{S}$ and activated protein C. J. Clin. Invest. 103(2), 219-227.

58. Smirnov, M.D. and Esmon, C.T. (1994) Phosphatidylethanolamine incorporation into vesicles selectively enhances factor Va inactivation by activated protein C. J. Biol. Chem. 269(2), 816-819.

59. Fournier, N., Paul, J.L., Atger, V., Cogny, A., Soni, T., Llera-Moya, M., Rothblat, G., and Moatti, N. (1997) HDL phospholipid content and composition as a major factor determining cholesterol efflux capacity from Fu5AH cells to human serum. Arterioscler. Thromb. Vasc. Biol. 17(11), 2685-2691.

60. Bertina, R.M., Koeleman, B.P., Koster, T., Rosendaal, F.R., Dirven, R.J., de Ronde, H., van der Velden, P.A., and Reitsma, P.H. (1994) Mutation in blood coagulation factor V associated with resistance to activated protein C. Nature 369(6475), 64-67.

61. Carson, S.D. and Ross, S.E. (1988) Effects of lipid-binding proteins apo A-I, apo A-IL, beta 2glycoprotein I, and C-reactive protein on activation of factor $\mathrm{X}$ by tissue factor--factor VIIa. Thromb. Res. 50(5), 669-678.

62. Lesnik, P., Vonica, A., Guerin, M., Moreau, M., and Chapman, M.J. (1993) Anticoagulant activity of tissue factor pathway inhibitor in human plasma is preferentially associated with dense subspecies of LDL and HDL and with Lp(a). Arterioscler. Thromb. 13(7), 1066-1075. 
63. Kokawa, T., Abumiya, T., Kimura, T., Harada-Shiba, M., Koh, H., Tsushima, M., Yamamoto, A., and Kato, H. (1995) Tissue factor pathway inhibitor activity in human plasma. Measurement of lipoprotein-associated and free forms in hyperlipidemia. Arterioscler. Thromb. Vasc. Biol. 15(4), 504-510.

64. Kawaguchi, A., Miyao, Y., Noguchi, T., Nonogi, H., Yamagishi, M., Miyatake, K., Kamikubo, Y., Kumeda, K., Tsushima, M., Yamamoto, A., and Kato, H. (2000) Intravascular free tissue factor pathway inhibitor is inversely correlated with HDL cholesterol and postheparin lipoprotein lipase but proportional to apolipoprotein A-II. Arterioscler. Thromb. Vasc. Biol. 20(1), 251-258.

This article should be referenced as follows:

Cuchel, M and Rader, D.J. (2002) The role of high density lipoproteins in thrombosis. TheScientificWorldJOURNAL 2 , 89-95.

\section{Handling Editor:}

Garret A. FitzGerald, Principal Editor for Thrombosis - a domain of TheScientificWorld. 

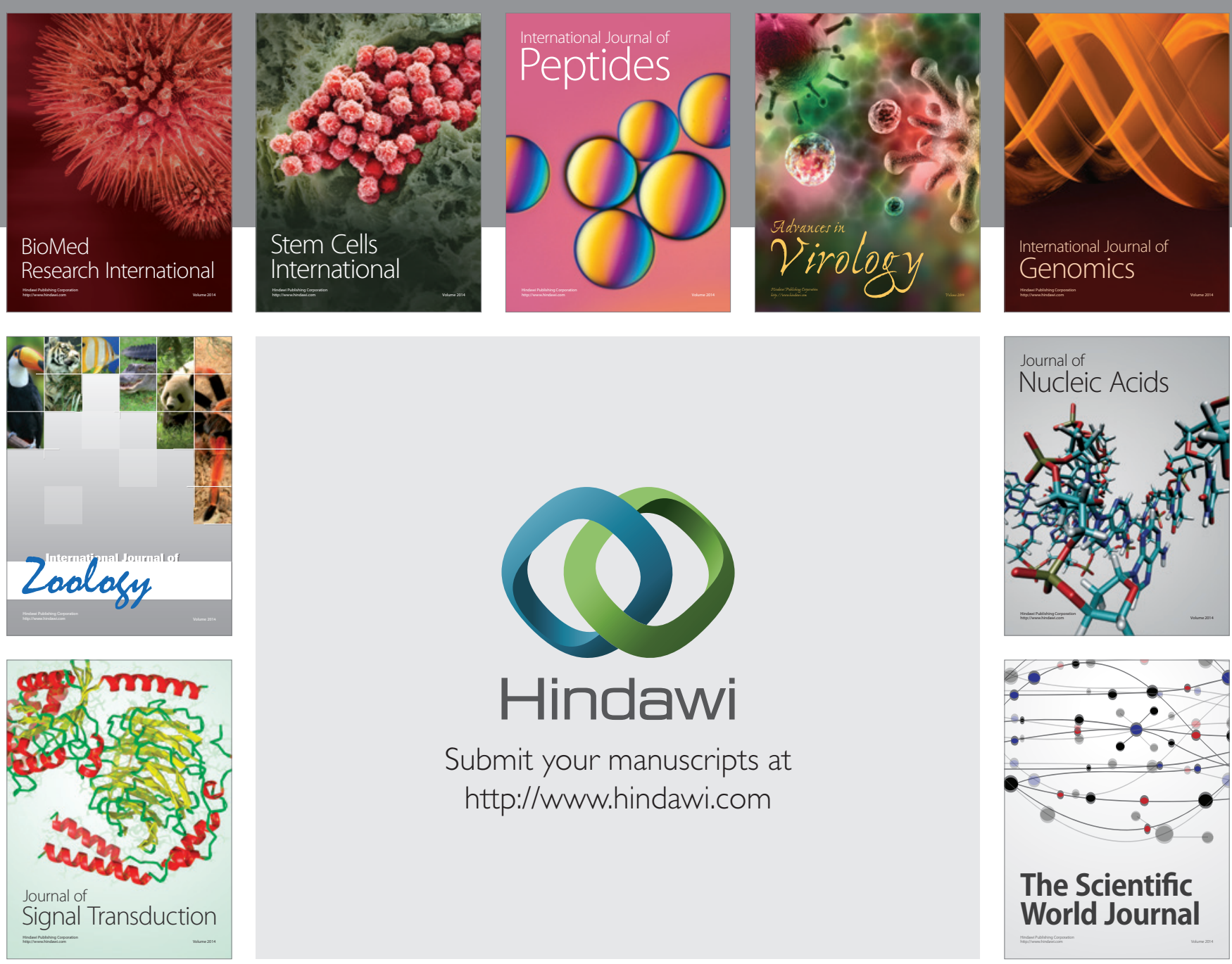

Submit your manuscripts at

http://www.hindawi.com
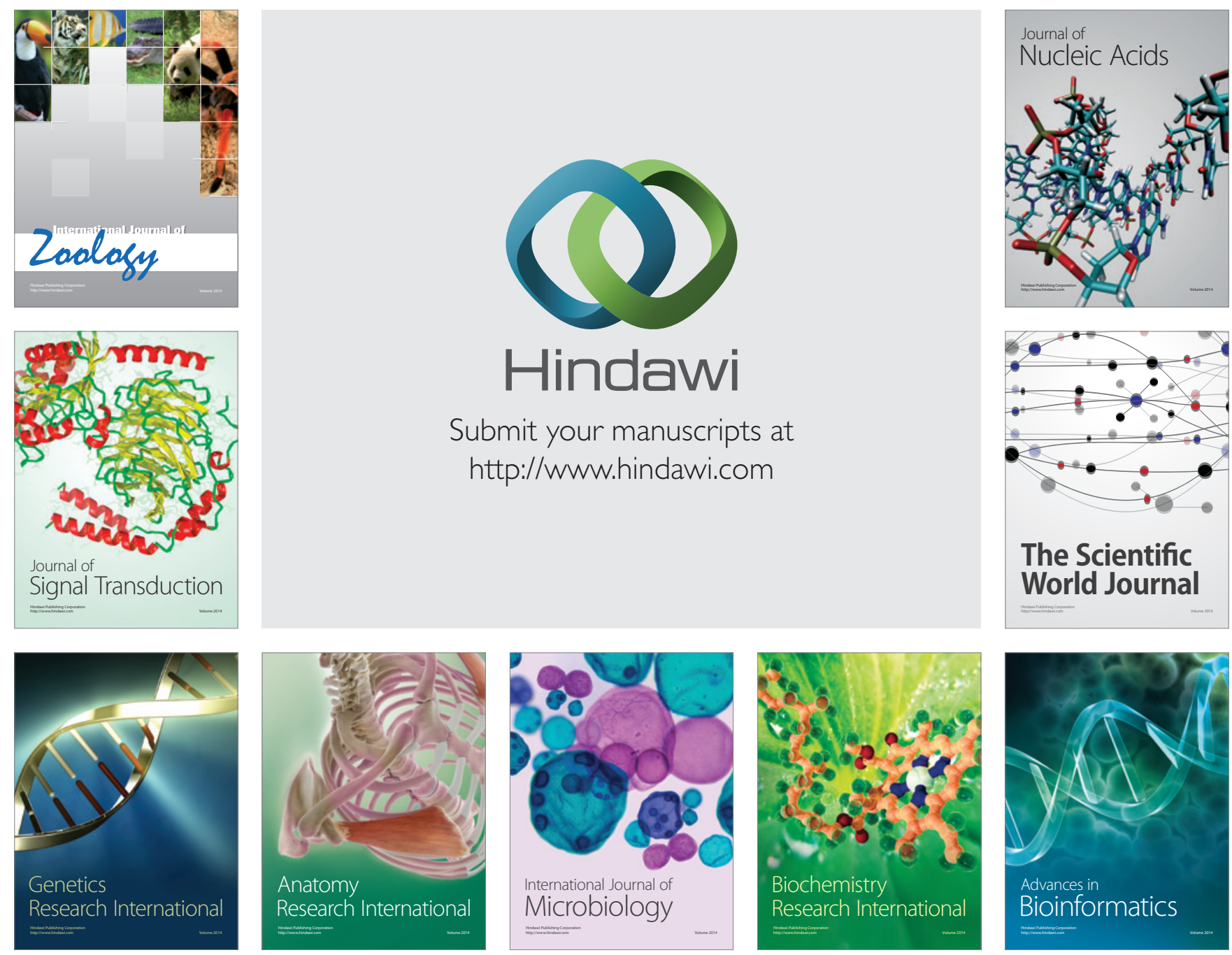

The Scientific World Journal
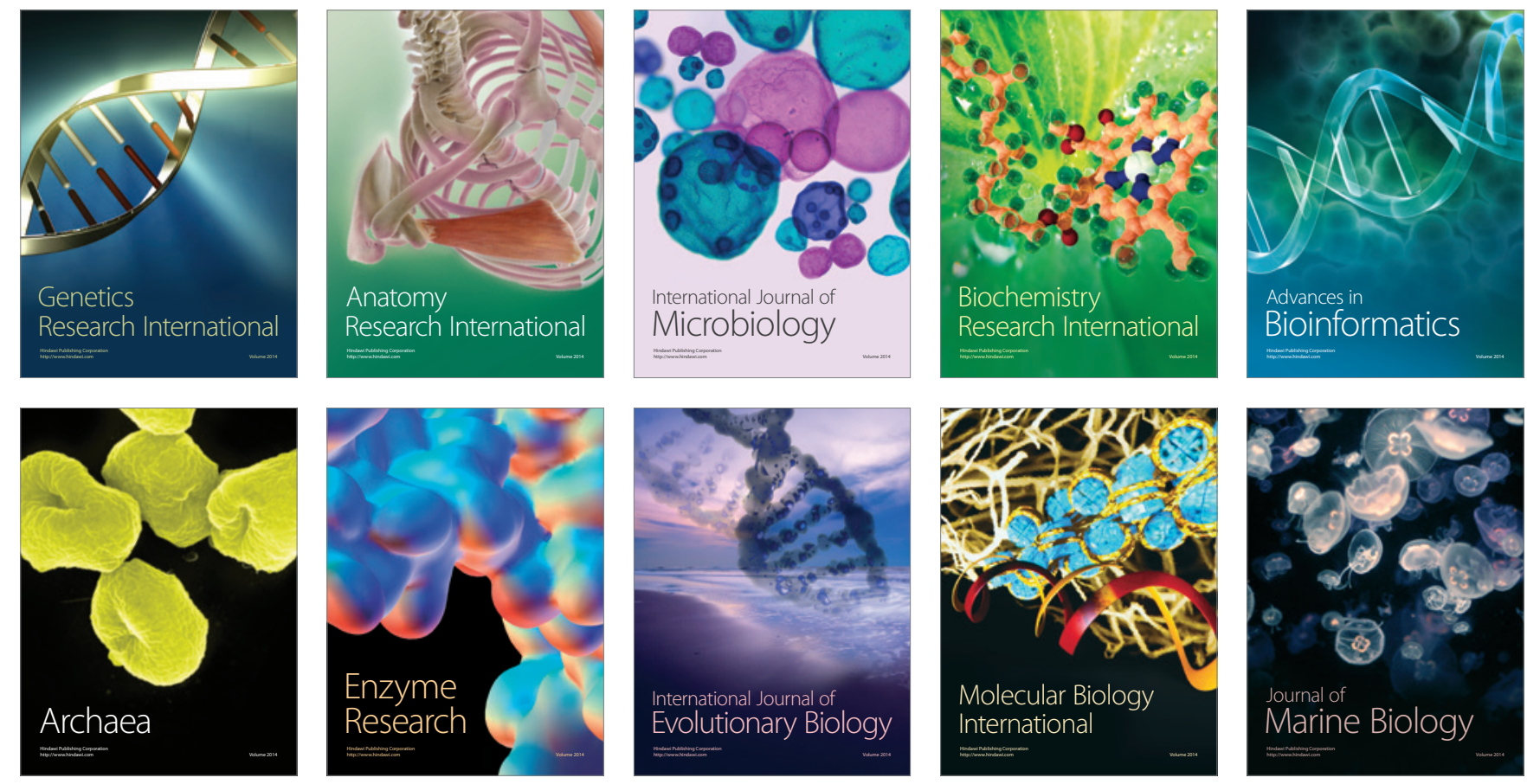